\title{
Students' Perception on Online Learning During the Covid-19 Pandemic
}

\section{(A Case study of Universitas Malikussaleh Students)}

\author{
Teuku Azhari ${ }^{1}$, Kurniawati $^{1}$ \\ ${ }^{1}$ Universitas Malikusssaleh \\ ${ }^{*}$ Corresponding authorE-mail: kurniawati@unimal.ac.id
}

\begin{abstract}
This study examines the students' perceptions towards online learning at Universitas Malikusaleh in Lhokseumawe City during the Covid-19 pandemic. This study reviews the perceptions of students at this higher education institution about the online learning process during the Covid-19 pandemic. The study covered the learning process, learning environment, and learning motivation. The method used in this research is a quantitative approach where the researchers distributed a self-administered questionnaire consisting of 16 items to the respondents online using Google Form. 100 respondents from Universitas Malikussaleh across faculties participated in the questionnaires. The data were then processed using SPSS Software. The results of the study exposed that students have negative attitude towards online learning during Covid-19 pandemic.
\end{abstract}

Keywords: Students' perspective, Online Learning, Universitas Malikussaleh

\section{INTRODUCTION}

The Corona virus (COVID-19) emerged in Wuhan, Hubei Province, China at the end of 2019. Since then, the virus has spread and attacked several countries such as Thailand, Japan and South Korea (Susilo et al., 2020). As of July 27, 2020, COVID-19 has spread to 215 countries and infected $16,648,616$ people with the number of deaths reaching 656,621 people globally. The United States, Brazil, and India became the countries with the highest number of sufferers with a total of 4,443,410, 2,446,397, and 1,484,136 respectively.

Since being declared a global pandemic by WHO, there has been great concern in all circles and levels of society. This has an impact on changing attitudes and behavior patterns in society, including the enthusiasm for learning. Due to the widespread of COVID-19, the government regulated online learning from elementary to university level. Online learning, also referred to as e-learning, is the use of modern information communication technology to convey instruction, information and teaching content (Selim, 2007) using internet (Arbaugh, 2000).

This has seriously affected students' attitude and performance in learning. Teachers/ lecturers plays important role in students' learning motivation (Azhari \& Dauyah, 2018). Contact and interaction with educators significantly contribute to their learning motivation.

Pandemic has forced education providers to run teaching and learning online. Teachers/ lectures had to teach in front of their computer/ laptop while also made students more dependent on the more dependent towards hand phone. This situation raises a big question mark for researchers to study students' perceptions of online learning during the Covid-19 pandemic.

This research studied and analysed Malikusssaleh University students' perceptions about online learning during the Covid-19 pandemic. This study covered the attitudes and perceptions of students during the online learning process as well as all matters related to the 
process such as the learning process, the learning atmosphere, and learning motivation.

\section{Factors Affecting Online Learning}

Several factors determined the success of online learning implementation. Learning facilities and infrastructure as well as the readiness of resources, including lecturers and students play key role in the success of online learning.

The factors discussed here, on the students' perspective were divided into three main areas, namely the learning process, the learning environment, and student learning motivation. Each aspect was sub-divided into detail. In terms of the learning process, the learning aspects discussed were students' perceptions of the delivery of material by lecturers, the ability to absorb material by students, and student learning outcomes. Meanwhile, the aspects of the learning environment studied were the places for implementing learning and the media used Motivation to learn is the last aspect examined. In detail, this aspect examined self-confidence in mastery of technology, self-confidence in independent learning, and confidence in online learning and communication.

\subsection{Students Perception towards Online Learning}

The learning process is a continuous activity that involves the absorption of knowledge, skills, and perspectives in attitude and behavior by those who are learning. Students' perceptions of the learning process include students' perceptions of the delivery of material by lecturers, the ability of students to absorb learning material during online learning and the results of student learning evaluations. Research conducted by (Aswasulasikin, 2020) showed that students feel boredom of online learning and students expect lecturers to be more creative and innovative to avoid boredom of online learning.

Research conducted by Adijaya (Adijaya \& Santosa, 2018) revealed that students felt that the interaction between students and lecturers during online learning was not optimal compared to learning in traditional classrooms. Students prefer face-to-face learning to online learning.

Meanwhile, in their research, (Astuti \& Febrian, 2019) found that students respond positively to online learning. Students feel more comfortable doing questions and answers in an online learning pattern than in face-to-face classes. They only experienced difficulties at the beginning of the meeting, then they were able to adjust because the instructions given were clear.
From several research results, it is revealed that the success of students in following the learning process online will be determined by accessibility to learning media and knowledge using technology which is very important because learning is not carried out in face-toface mode but uses media based on information and communication technology.

\subsection{Students Perception towards Learning Environment}

Several studies have shown that the learning environment affects the success of learning. In terms of online learning, this includes a place for implementing learning and the media used for learning.

In online learning, the media used by lecturers and students varies. Generally, both students and teacher/ lecturer use social media and video conference apps for online learning. They can interact with each other through the use of applications such as e-classroom, video conference, telephone or live chat, zoom or WhatsApp Group (Dhull Indira, 2017).

Currently, the most popular online learning media are WhatsApp and Google Classroom. On the other hand, learning with the use and utilization of technology has made the learning atmosphere more enjoyable and comfortable (Bali \& Liu, 2018). By using technology to study, students feel they have a greater opportunity to be more innovative.

\subsection{Students Perception towards Motivation for Online Learning}

Motivation comes from the word 'motive' which means encouragement or things that become a reason for doing something. In the learning process, motivation plays an important role and is a major requirement in learning.

In online learning, motivation also has an important contribution to support student learning. Motivation to learn through online learning increases due to the use of innovative technology (Wida, 2020). Students become more motivated and involved in online learning because several things such as topics that are teaching material that students like and existing prior knowledge about the use of media used in learning such as how to use computers.

In the midst of a pandemic, there is no other choice but to carry out learning online. Even though it is done online, students still have high motivation in following the learning process in terms of concentration, curiosity, enthusiasm, independence, readiness, enthusiasm or 
encouragement, never giving up, and self-confidence (Fitriyani, Fauzi, \& Sari, 2020).

\section{METHODOLOGY}

\subsection{Subject}

The subject of this research was the students of Universitas Malikussaleh (Unimal). Inclusion criteria used were active students studying at Universitas Malikussaleh across faculties and semester as well as gender. 100 students across the faculties participated in this survey. Unimal is a state university located at $\mathrm{Jl}$. Cot Tgk Nie Reuleut, Muara Batu, North Aceh, Aceh.

\subsection{Method}

Sampling method used was purposive random sampling. Researchers distributed questionnaires using Google Form and questionnaire items were translated into Indonesian. The questionnaire was self-administered and developed through a comprehensive literature search. It consisted of 16 questions and the responses are based on 5-point Likert Scale - 1 (strongly disagree), 2 (disagree), 3 (somewhat agree), 4 (agree), and 5 (strongly agree). The questions investigated the views of Universitas Malikussaleh students towards online learning. The 16 questions in the questionnaire were then categorized into three groups: the perception of students towards learning process (7 items), students' views on online learning environment including the use of technology (5 items), and their motivation in learning online (4 items).

\section{RESULT AND DISCUSSION}

\subsection{Students' perception towards learning process}

Table 1 below provides the descriptive statistics of the students' perception towards online learning particularly towards the learning process. Out of 7 questions, only 2 questions has a Mean above 3, the other 5 is 2 or below. In average, students' respondents Mean score is 2.61, less than 3. Detail Mean scores is elaborated as follows.

\begin{tabular}{|l|r|r|r|r|r|}
\hline & $\mathrm{N}$ & $\begin{array}{c}\text { Minimu } \\
\mathrm{m}\end{array}$ & Maximum & $\begin{array}{c}\text { Mea } \\
\mathrm{n}\end{array}$ & $\begin{array}{c}\text { Std. } \\
\text { Deviation }\end{array}$ \\
\hline Q_1 & 100 & 1 & 5 & 3.03 & 1.039 \\
Q_2 & 100 & 1 & 5 & 2.70 & .980 \\
Q_3 & 100 & 1 & 5 & 3.13 & 1.203 \\
Q_4 & 100 & 1 & 5 & 2.65 & 1.123 \\
Q_5 & 100 & 1 & 5 & 2.58 & 1.148 \\
Q_6 & 99 & 1 & 5 & 2.36 & 1.336 \\
Q_7 & 100 & 1 & 5 & 1.82 & 1.067 \\
Valid N & 99 & & & & \\
(listwise)) & & & & & \\
\hline
\end{tabular}

from the lecturers. Scoring indicated less satisfactory perception on online learning as more students' claimed in-activity of the process for maximum outcomes. Classroom process contributed greatly to learning outcomes (Tanta, 2010). Visual attributives in teaching learning contributed to students' learning and retention.

Even though has been utilized by many educational administrators, still, some found online learning not as effective as face-to-face learning. However, this is not to assume that online leaning is not effective at all. Merely, it is a comparative statement as they expressed their preferences to classroom teaching. (Mukhtar, 2017) indicated similar finding saying that up to $80 \%$ of students reported positive attitude towards the use of the Facebook as a sharing platform.

\subsection{Students' Perception towards learning environment}

Table 2 presents the descriptive statistics of students' perception towards learning environment. This category comprises of 5 items.

\begin{tabular}{|l|r|r|r|r|r|}
\hline & $\mathrm{N}$ & $\begin{array}{c}\text { Minimu } \\
\mathrm{m}\end{array}$ & Maximum & $\begin{array}{c}\text { Mea } \\
\mathrm{n}\end{array}$ & $\begin{array}{c}\text { Std. } \\
\text { Deviation }\end{array}$ \\
\hline Q_8 & 100 & 1 & 5 & 3.29 & 1.094 \\
Q_9 & 99 & 1 & 5 & 2.46 & 1.215 \\
Q_10 & 100 & 1 & 5 & 2.57 & 1.350 \\
Q_11 & 100 & 1 & 5 & 2.56 & 1.149 \\
Q_12 & 100 & 1 & 5 & 2.73 & 1.238 \\
Valid N & 99 & & & & \\
(listwise) & & & & & \\
\hline
\end{tabular}

In general, students responded positively towards the use of the platform in online learning. They experiences little to issues, apart from the internet connection. Internet connection, also experienced by students at Universitas Kristen Satya Wacana (Tanta, 2010), and package were main issues for many. They experienced internet lagging and had to spend more on internet quota. Thus, the situation made it less favorable for the students.

At the beginning, few students experienced technology gap in the online learning, but now they became more familiar with all the platforms. On the other side, however, as lecturers utilized different platform when teaching their courses, students had to deal with several applications, which took a lot of their hand phone/ lap top hard drive memory. Accessing the subject at home created a two-layer effect. On one side, students loved it, but on the other, they became distracted and less motivated. This fact was also corroborated by a study conducted by N. Dewi L et.al as they found students' habit in accessing the lesson impacted their intake (Dewi, Tripalupi, \& Artana, 2015).
These items questions asked about clarity of delivery by the lecturers and students' ability in task accomplishment 


\subsection{Motivation of Students in online learning}

Third set consisted of 4 items querying on their learning motivation in online learning as well as their level of confidence over their own understanding. Students claimed that they were relatively motivated, however their level of understanding were distorted by the internet connection and lecturer's perception over the subject level. Some lecturers skipped materials they thought simple and understandable by the students. Thus, the skipped materials causes gap of understanding on students' side.

\begin{tabular}{|l|r|r|r|r|r|}
\hline & $\mathrm{N}$ & $\begin{array}{c}\text { Minimu } \\
\mathrm{m}\end{array}$ & Maximum & $\begin{array}{c}\text { Mea } \\
\mathrm{n}\end{array}$ & $\begin{array}{c}\text { Std. } \\
\text { Deviation }\end{array}$ \\
\hline Q_13 & 100 & 1 & 5 & 2.47 & 1.150 \\
Q_14 & 99 & 1 & 5 & 2.45 & 1.062 \\
Q_15 & 100 & 1 & 5 & 2.32 & 1.053 \\
Q_16 & 100 & 1 & 5 & 2.55 & 1.313 \\
Valid N & 99 & & & & \\
(listwise) & & & & & \\
& & & & & \\
\hline
\end{tabular}

Students' motivation is crucial in maintaining their interest and motivation in learning (Azhari \& Dauyah, 2018). Other factor that come into play is learning independence and self-confident (Amina, 2013). Students at Malikusaleh University, however, claimed that they had not developed such learning habits yet, which in turn affect negatively to their study. Descriptive analysis from the questionnaires also noted low scores in this factor, which means low self-efficacy and self-confidence in their grasp of the material. Teaching process, especially with internet issue and skipped materials, have caused negative impact to their motivation and self-confidence.

\section{CONCLUSION}

Based on the results of the research, it can be concluded that online learning is less preferable for students compared to face to face learning. It is less preferable as it is less effective in terms of the learning and teaching process. Besides, online learning also poses some constraints including the availability of adequate internet network needed to access online learning. Students also felt less motivated in online learning when compared to learning in a traditional classroom.

A future research, particularly qualitative research is needed to gain more understanding on this issue and to explore more on why students felt online learning is less effective especially during the Covid-19 pandemic. 


\section{REFERENCES}

Adijaya, N., \& Santosa, L. P. (2018). Persepsi Mahasiswa dalam Pembelajaran Online. Wanastra, 10(2), 105-110.

Amina, Z. (2013). Pengaruh Kemandirian dan Rasa Percaya Diri Siswa Terhadap Hasil Belajar IPA pada Siswa Kelas IV di SD Negeri 2 Krangganharjo Tahun Ajaran 2012/2013.

Arbaugh, J. B. (2000). Virtual Classroom Characteristics and Student Satisfaction with Internet-Based MBA Courses. Journal of Management Education, 24(1), 32-54. https://doi.org/10.1177/10525629000240 0104

Astuti, P., \& Febrian, F. (2019). Blended Learning Syarah: Bagaimana Penerapan dan Persepsi Mahasiswa. Jurnal Gantang, 4(2), 111-119.

https://doi.org/10.31629/jg.v4i2.1560

Aswasulasikin, A. (2020). Persepsi Mahasiswa Terhadap Kuliah Daring dimasa Pandemi Corona Virus Disease (COVID-19). SALAM: Jurnal Sosial Dan Budaya SyarI, 7(8). https://doi.org/10.15408/sjsbs.v7i8.15734

Azhari, T., \& Dauyah, E. (2018). Learning Motivation of Peripheral University Students and its Relation with their English Grades. Emerald Reach Proceeding Series, 1, 473-478. https://doi.org/10.1108/978-1-78756-7931-00028

Bali, S., \& Liu, M. C. (2018). Students' perceptions toward online learning and face-to-face learning courses. Journal of Physics: Conference Series, 1108(1). https://doi.org/10.1088/17426596/1108/1/012094

Dewi, N. G. A. A. L., Tripalupi, L. E., \& Artana, M. (2015). Pengaruh pelaksanaan pembelajaran dan kebiasaan belajar terhadap hasil belajar ekonomi kelas $\mathrm{x}$ sma lab singaraja. Pendidikan, 1, 1-10.
Dhull Indira, S. M. (2017). Online Learning. IERI, 3(August), 32-34.

Fitriyani, Y., Fauzi, I., \& Sari, M. Z. (2020). Motivasi Belajar Mahasiswa Pada Pembelajaran Daring Selama Pandemik Covid-19. Profesi Pendidikan Dasar, 7(1), 121-132. https://doi.org/10.23917/ppd.v7i1.10973

Mukhtar. (2017). Persepsi Mahasiswa terhadap Pelaksanaan Perkuliahan dan Hubungan dengan Partisipasi dalam Perkuliahan. Jom FISIP, 3(3), 2-4. Retrieved from http://dx.doi.org/10.1016/j.moem.2017.07 $.001 \%$ AAttp://dx.doi.org/10.1016/j.lithos .2014.07.017\%0Ahttp://dx.doi.org/10.101 6/j.mspro.2015.11.130\%0Ahttp://dx.doi.o rg/10.1016/j.jmmm.2010.01.018\%0Ahttp: //dx.doi.org/10.1016/j.jmrt.2014.07.001\% 0Ahttp://dx.doi.org

Selim, H. M. (2007). Critical success factors for e-learning acceptance: Confirmatory factor models. Computers and Education, 49(2), 396-413. https://doi.org/10.1016/j.compedu.2005.0 9.004

Susilo, A., Rumende, C. M., Pitoyo, C. W., Santoso, W. D., Yulianti, M., Herikurniawan, H., ... Yunihastuti, E. (2020). Coronavirus Disease 2019: Tinjauan Literatur Terkini. Jurnal Penyakit Dalam Indonesia, 7(1), 45. https://doi.org/10.7454/jpdi.v7i1.415

Tanta. (2010). Pengaruh Gaya Belajar terhadap Hasil Belajar Mahasiswa pada Mata Kuliah Biologi Umum Progaram Studi Pendidikan Biologi Universitas Cendrawasih. Jurnal Pendidikan Dasar, 1(September 2010), 7-21.

Wida, S. (2020). Respon Mahasiswa Pada Mata Kuliah Daring. Child Education Journal, 2(1), 48-52. https://doi.org/10.33086/cej.v2i1.1506 